CATHARSIS 9 (3) 2020

Halaman: 220-228

p-ISSN 2252-6900 I e-ISSN 2502-4531

UNNES

Catharsis: Journal of Arts Education

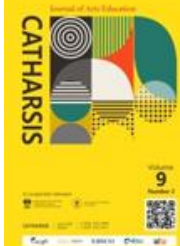

http://journal.unnes.ac.id/sju/index.php/chatarsis

\title{
An Implementation of Reflective Pedagogy in Hybrid Music Learning
} of Gamelan Soepra

\author{
Benidiktus Candra Pamungkas $^{1 凶}$, Udi Utomo ${ }^{2}$, Totok Sumaryanto Florentinus ${ }^{2}$ \\ E-mail: benidiktusc@gmail.com \\ 1. SMI Learning System, Sekolah Musik, Indonesia \\ 2. Universitas Negeri Semarang, Indonesia
}

Received 27 April 2020, Accepted 23 August 2020, Published 23 December 2020

\begin{abstract}
Gamelan Soepra is a gamelan instrument that has been changed in tonality to diatonic and has a higher wadhah. With its diatonic tonality, Gamelan Soepra is able to be combined with today's modern instruments and it is able to play many song. The uniqueness of the Gamelan Soepra was used by Pater van Deinse as a music education at SMA Kolese Loyola. Gamelan Soepra is a tool for educating thar is combined with reflective pedagogy as an educational method. Reflective pedagogy has several elements, namely: context, experience, reflection, action, and evaluation. This study aims to understand the implementation of the reflective pedagogy elements in the learning process of Gamelan Soepra. The methods used by the author in collecting data were observation, interview, and document study. Gamelan Soepra Learning through reflective pedagogy not only develops students' abilities in playing music (Competence), but students also are trained to hone and develop their conscience (Compassion), conscience and their commitment and responsibility to what they have chosen (Commitment). This $s$ is study expected to be a reference for developing learning methods, especially music learning
\end{abstract}

Keywords: Gamelan, Reflective Pedagogy, Hybrid Music

DOI : https://doi.org/ 10.15294/ catharsis.v9i3.44612 


\section{INTRODUCTION}

Gamelan generally uses the pentatonic pelog and slendro tone, but Gamelan Soepra uses the western diatonic tone. This is a form of hybrid music that combines two elements, namely west and east. Amica (2017: 89) states that hybridity includes efforts to "combine" cultural elements that were previously separate with the aim of producing various new meanings and identities. In the art works, especially music, the form of hybridity music has two distinct musical cultural elements. Musical hybridity can occur when the culture of one nation is merged with the culture of another, in Soepra there was post-colonialism after the Dutch colonized Indonesia. Music brought by the Dutch circulated widely in Indonesia and then there was a meeting with traditional music in the form of Javanese Gamelan. The form of Gamelan Soepra is similar to the Javanese Gamelan but the difference lies in the greater number of wilah and wadhah or wooden places to place wilahwilah Gamelan that has tall like a table (Nugroho, 2008: 176). The wadhah that is tall is formed so that the Gamelan can be played sitting or standing like playing the keyboard or piano. However, the character of the Gamelan voice still can be heared the same regardless of the scale played. Gamelan Soepra is the creative product of Pastor Van Deinse, S.J. in processing music as a means of education (art education). In other words, Soepra as a tool for educating students and reflective pedagogy is a way of educating students. Reflective pedagogy is an educational model that is applied throughout all college schools. The combination of Soepra and reflective pedagogy to achieve the goals of education at SMA Loyola is the subject of this study.

Aryanto (2018) in his writing suggests that Gamelan Soepra is a western Javanese Gamelan that is contained in the diatonic scale used, it eliminates the influence of Javanese Gamelan. However, there is learning methods that teach cooperation, discipline, and responsibility to students. Plato in Wibowo (2017: 51) states that education is based on a view of humans. The soul is the core of humans so education should refer to developing the soul of students and directing it according to the potential that students have. The body also needs to be educated properly along with educating the soul and mind, so that the ideal human according to Plato can be realized.

Nugroho (2008: 4) stated that the Society of Jesus has educational goals that want to develop their students "be a man and woman with and for others". Education is not only centered on intellectual aspects but also in students who have a conscience, care, a sense of wanting to share and have a commitment in life. Humans who live together and they are willing to cooperate with others.

Reflective pedagogy has three main elements, namely Experience, Reflection, and Action (Subagya, 2010: 37-38). Context and evaluation are the supporting elements of the three elements above. Context is a place where experiences and evaluations take place after the action has taken place. These elements move in a spiral step which aims after the evaluation takes place students gain new experiences.

Soepra was formed as an answer to the socio-political situation at that time (Nugroho, 2008: 161). Pater Jan van Waayenburg, S.J. as the principal of SMA Kolese Loyola, he is worried about Indonesian youths who are left to fight by their parents or those who fought to defend Indonesia's independence. Pater Van Deinse, S.J. created Gamelan Soepra in 1957. Chromatic gamelan is the initial name for Soepra because the scale used is diatonic chromatic (Aryanto, 2018: 112).

On the other hand, maintaining culture as an identity is very important, in line with Widodo (2018: 9):

"Traditional arts as a crystallization of national cultural values can be used as a medium and recognize them as a way to get to know them more deeply. With this understanding and experience, they will grow a sense of handarbeni (owning and appreciating), 
hangrungkebi (taking part in guarding), mulat sarira hangrasa wani (seeing, confident, and brave) so that they are proud to be the Indonesian nation".

Likewise, according to Sukari (2012: 216) Traditional art is the identity and expression media of the community that supports it. Thus, Gamelan Soepra can be a means of introducing and giving students an understanding of Gamelan. The experience gained from learning Gamelean Soepra can foster students' love for Gamelan and indirectly they will protect and preserve Javanese Gamelan.

Gamelan Soepra is considered unique, a traditional instrument that is considered different because it is made on a diatonic scale, giving rise to an atmosphere of western music but with Javanese sound (eastern music). It is not only about that, Van Deinse's goal in Gamelan Soepra which aims to foster a love for local culture but still open to global culture is one of the interests of researchers to study Gamelan Soepra. The reflective pedagogy used in all college schools is a reference for researchers in photographing the learning process in Gamelan Soepra. The purpose of this reflective pedagogy is to develop students' competence and character. The character of students is formed to increase their love for local culture while remaining open to global culture. The interesting in reflective pedagogy is the process of providing experience related to the development of factual, conceptual, procedural knowledge, skills, and aesthetic values. The aesthetic values in Gamelan Soepra will be used as a means of developing student character. Thus, in this study, it is more focused on the process of providing experiences and learning experiences for students in participating in Gamelan Soepra learning.

\section{METHODS}

The approach used in this study is Musicology and Art Education with a qualitative research model. Researchers conducted observations, interviews, and document studies to collect data related to
Gamelan Soepra learning. The data is divided into two, namely primary data and secondary data. Primary data is data taken directly by researchers, namely the results of observations, interviews, and documentation. Then secondary data is supporting data contained in the reality, namely in the form of books and writings on reflective pedagogy and Gamelan Soepra. Observations were conducted by researchers during the teaching and learning process, researchers also took part in teaching Gamelan Soepra. Interviews were conducted with resource persons who work as Gamelan Soepra teachers, the principal of SMA Kolese Loyola, and Gamelan Soepra students. Video and photo documentation contains the teaching process of Gamelan Soepra and Gamelan Soepra performances. Literature data are writings, books, papers, and articles on Gamelan Soepra and reflective pedagogy. The data would then be processed by using interactive data analysis techniques. The analysis is divided into 3 parts, namely: (1) Data Reduction, (2) Data Presentation, (3) Verification or Drawing Conclusion.

\section{RESULTS AND DISCUSSION}

\section{History and Instruments of the Gamelan Soepra}

1957, Pather Van Deinse, S.J. created a set of gamelan with a diatonic tone called Gamelan Chromatic (Aryanto, 2018: 112). Then the name Soepra was added by Soekarno at the closing night of the 5th Catholic Youth Congress and the Catholic Front Pioneer Cadre Education as well as the opening of the VIII Catholic Party Congress at the Bung Kamo Istora Senayan, Jakarta. The incident occurred on July 22, 1965. The name of Soepra was chosen to commemorate Mgr. Soegijapranata, S.J. who had died 2 years on July 22, 1963 (Nugroho, 2008: 165). Gamelan Soepra has a high wadhah that makes it possible to play it by sitting or standing. 


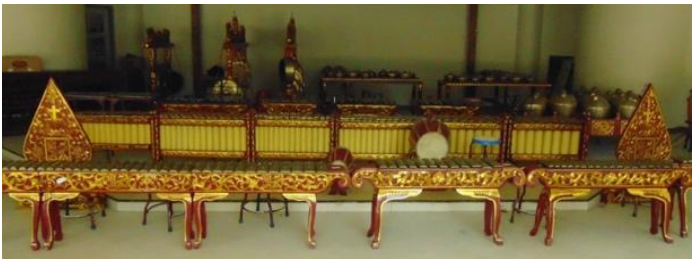

Figure. 1 Wadhah of Gamelan Soepra

Van Deinse has a desire that children who learn Gamelan Soepra can love local culture and be open minded to global culture. The local culture is Gamelan which has a diatonic scale and it is combined with western musical instruments namely combo bands which are the embodiment of global culture.

\section{Reflective Pedagogy}

Art education in schools namely aims to provide students with various competences in the fields of creation and appreciation (Rondhi, 2017: 9). According to Wahana (2015: 16) There are three focus of education, namely knowledge building, skills building, and character building. Based on the three elements of education, the point is only one of them, namely character. Character is the product of culture. In line with the above statement, according to (Sumaryanto, 2000: 39) the aim of handicrafts and arts subjects in schools generally is to develop students' attitudes and abilities to be creative and appreciate handicrafts and arts. Music education at SMA Loyola does not only teach music creation and appreciation, but students are also educated to care for the environment and others.

SMA Loyola applies reflective pedagogy which has 5 main elements, namely: context, experience, reflection, action and evaluation. The five elements are interrelated and should form a strong link for the success of a learning process. A good learning process aims to achieve the vision and mission of education in an educational institution.

\section{Context}

Context in reflective pedagogy is an important element that must be understood by teachers in the learning process. Context consists of two things, namely: the conditions of the learning environment and the student's personality.

\section{Learning Environment}

The learning environment is a place for teaching and learning process. The learning environment greatly influences to the teaching and learning process and outcomes. According to researchers' observations, the environment at SMA Kolese Loyola is very conducive to a good learning process even though it is located in a residential area. The environment of SMA Kolese Loyola is very quiet during the teaching and learning process.

\section{Student Personal}

The role of students is to be able to develop their personality in accordance with their independence as humans, decide choices, make decisions, and explore themselves with the uniqueness and characteristics they have (Desyandri, 2015: 12). Therefore, education should be able to facilitate student personality development. Of course, personality development becomes a better person. This personality can be directed towards a better education (Allport in Maryani, 2002: 355). According to Ross in Rondhi (2017: 9) artists are not special people, but everyone is an artist with special abilities. Purwanto in Maryani (2002: 355) emphasizes that personality is more peculiar to each individual.

The majority of students were interested in learning Gamelan Soepra which was based on several things, including: (1) students had basic music or had studied music before (2) students wanted to try playing Gamelan Soepra because of their deep curiosity about Soepra's uniqueness (3) Motivation and invitations from family and friends to become part of Gamelan Soepra.

In Gamelan Soepra learning, the relationship among students and between students and the teacher is emphasized at the beginning of learning. It is hoped that students can share ideas with their friends and teachers. Gamelan Soepra is a means of developing 
student personalities who have competence, compassion, concern and commitment or it is called 4C (Competence, Compassion, Conscience and Commitment). Art education as a subject in schools can be an effective medium in developing students' knowledge, skills, creativity, and sensitivity in building personality (Widodo 2010: 12; Sugiarto, 2019: 17).

\section{Experience}

Experience is one of the fundamental things that students get various information about what they learn. Experience is one of the factors in the process of changing student behavior while studying (Sugiarto, 2013; Sumaryanto, 2005: 3). Experience in reflective pedagogy is divided into two, namely direct experience and indirect experience.

\section{Direct Experience}

Soepra's learning is divided into 3 sessions, namely: ice breaking, material, and closing. Ice breaking contains fun games, which aim to provide refreshing time for students who in the previous time had learned lessons that focus on theory. Subjects such as mathematics, science, and social studies are often considered boring by students. In the ice breaking session, students could experience fun social interactions with peers and to the teacher. Therefore, ice breaking was also a means for students and teachers to build relationships. The relationship that was meant by the closeness and comfort of students to the teacher, but still within the limits of a teacher must be appreciated and respected. Good relationships also create a conducive learning atmosphere, because students do not feel relaxed, bored, and even afraid of the teacher.

Playing ensemble music or in Gamelan Soepra can be called a karawitan which requires cooperation and solidarity in order to create beautiful music. Good cooperation must be based on mutual trust and understanding between students. Then, practicing musical music can foster a sense of care for others. Character is expected to be implemented by students in their environment outside of the school.

The performance of Javanese gending is conducted as if people are doing discussions with a considerable number of questions and answers. If the questions and answers in discussion are conducted verbally, then, in karawitan it employs the sounds of ricikan and vocal (Widodo, 2015:43).

This means that Javanese music performances are performed as if people were having a discussion with quite a lot of questions and answers. If the question and answer in the discussion is carried out orally, then in karawitan uses the sound of chirps and vowels. Communication is important in the Gamelan Soepra music game. Good communication will result in good cooperation among students to produce beautiful music games. Communication can also foster mutual trust which then emerges care among these students. This understanding is cultivated by teachers to their students.

Conscience is related to honesty and student responsibility. A person can also experience a crisis of values, morals, and norms. Currently, there is a crisis of trust, a crisis of quality of independence or a crisis of character, a crisis of values which is the reference and guide in the life of the nation and state (Djahiri in Santoso, 2016: 12). Honesty is an important thing for students to be possessed, especially in their role as learners.

Honesty is cultivated to students in every Soepra learning activity. Thus, students are not afraid to act and tell the truth. Responsibility is cultivated through students in preparing their respective instruments, hitters, stand parts, and scores. Students are also given the responsibility of tidying up the tools and saving their scores after class.

Commitment is related to the commitment of students in their choices and in completing their assignments and responsibilities. Commitment is emphasized to students in playing an instrument as well as their participation in the Soepra extracurricular. Students often feel bored 
playing the same instrument over and over again. This is because the instruments they play are too easy. Then it also found that students find difficult to score the instruments they played. In this case the teacher always cultivates a commitment to what they choose. Students are encouraged to be enthusiastic and finish the song material even if it is difficult or bored. Teachers always help students who have difficulties, so that these students can be helped in taking the parts of difficult things for them.

\section{Indirect Experience}

Indirect experience is the experience that is got by students through information around students, namely books, websites and teacher explanations. In learning Gamelan Soepra, students were not only required to play the gamelan but also had to understand the history of Gamelan Soepra and read notation. The history of Gamelan Soepra is something that students must know, namely who created Gamelan Soepra and what Gamelan Soepra is like. Students must also be able to read notation to be able to play Gamelan Soepra. Block notation and numerical notation were taught in Gamelan Soepra learning.

Giving material is not only focused on the teacher, but the teacher also encourages students to look for various information about Gamelan Soepra from various sources. An adequate internet network is one of the means that makes it easier for students to find this information anytime and anywhere.

\section{Reflection}

Reflection activity in the form of examine (inner examination) which is carried out before school time is up. The examination was carried out simultaneously and was guided by a speaker which contained several questions and a prayer that closed the activity. The questions in the examination were as follows: (1) Did your plan yesterday have been carried out today? (2) what experiences did you have today? (3) What was the most memorable thing for you? (4) What plans will you do tomorrow? The first question was an evaluation of the student's plan that he had drawn up in the previous day. Then the next three questions are a material for students' reflection about what they get during in one day of study. The most memorable experiences are those that will be processed further. However those experiences.

Reflection in Soepra's class always begins with questions from the teacher about what students get in the teaching and learning process. This activity is carried out at the end of class and in addition to the examination. In this activity, the teacher gives time to students who want to share their experiences. Then the most important thing is that the teacher always emphasizes the basic meanings of playing Gamelan Soepra, namely: cooperation, discipline, commitment and responsibility.

\section{Action}

The meanings that students got then would be implemented in their lives. In Gamelan Soepra, students could work together to play songs well. More than that, the elements taught in Gamelan Soepra could be implemented in social life. The 4C elements, namely: Competence in music could be use for teaching or servicing in the Church. The attitude of compassion and conscience of students could be implemented in various situations and places to help each other and create peace. The commitment attitude that students had was able to develop a sense of responsibility and never gave up on students in carrying out all activities.

\section{Evaluation}

The evaluation of Gamelan Soepra learning was carried out by assessing students' understanding of the material that had been provided by the teacher. The assessment was done through practical tests and written tests. The practice test aimed to assess students' skills and attitudes in playing gamelan music. The written test aimed to assess students' knowledge of music theory and the philosophy of Gamelan Soepra. According to Riadi (2017) evaluation in education occurs when the teaching and learning process is systematic and consists of 
many components and evaluation that is useful for improving teaching programs.

The Gamelan Soepra learning curriculum is divided into 2 aspects, namely: knowledge aspects, skills aspects, and attitude aspects. Knowledge aspects are divided into 5 basic competencies, (1) describing basic music theory (2) reading notation (3) identifying accidental signs (4) explaining the background and history of Gamelan Soepra (5) reflecting the philosophical meaning of Gamelan Soepra. The skill aspect is divided into 5 basic competencies, (1) demonstrating the performance of one of the melodic gamelan instruments (2) demonstrating the melody performance correctly (3) demonstrating the melody performance with the right rhythm (4) demonstrating the perfformance of one of the non-melodic gamelan instruments (5) demonstrating performance of a non-melodic gamelan instrument with the appropriate tempo.

\section{Written Test}

The written evaluation of Gamelan Soepra was carried out 3 times in one semester. Assessments were in the form of assignments, written tests, and end-of-semester assessments. According to the student score data, each basic competency in knowledge aspects has 2 values, namely: the score of the assignment and the score of the written test. The score of each $\mathrm{KD}$ will be averaged and added to the end of seemester score. The average of the total score will be the final score of the students. The written assessment aims to test aspects of students' knowledge about music theory, the instruments in Gamelan Soepra, and the history of Gamelan Soepra. This knowledge is very important so that students can play Gamelan Soepra well. Music theory must be understood so that students can read song scores correctly and then students can apply it to the Gamelan Soepra instrument. Gamelan instruments have different types and different ways of playing, therefore students are required to understand each gamelan instrument. Gamelan Soepra is a group that was created for a long time and of course there are changes and developments. Students are expected to understand how and who created Gamelan Soepra. Then students are also expected about the purpose of the Gamelan Soepra being created, it is about preserving Javanese culture which remains open to global culture. So students can not only play gamelan but can also love and preserve Javanese culture and stay up to date with the times.

\section{Practice Tests}

A Gamelan game that requires regular practice, discipline, and good cooperation. Therefore, in Gamelan Soepra, a practical assessment was carried out to find out the results of the students' training

Assessment in Extra Gamelan Soepra is usually based on attitude score during the training process, if during the practice is certainly good then the performance is also good. It is automatically make their score is also good. (Interview with Iwan, 8 August 2019)

The practical assessment was carried out at the end of the semester which aims to test the results of individual student exercises and group exercises. The aspects that were assessed in the test were individual abilities, harmony, and cooperation. These aspects are divided into 5 basic competencis and each basic competensis has 1 score. The average of the total scores for all basis competencis would be the student's final score.

\section{Teachers' Observation}

Not all students have the same musical ability and interest in Gamelan Soepra. Because of these differences, teachers should make observations to students in the teaching and learning process. Observations by the teacher were carried out in order to see the development of student learning. The developments observed were related to student skills, student knowledge and student attitudes. Thus, the teacher could identify students with fast development and slow development. Then the teacher could provide appropriate treatment for their students. 
The teacher's responsibility was to provide encouragement and more teaching for these students. Teachers could also compile more interesting learning models so that their students were more interested and happier to learn Gamelan Soepra.

\section{Assessment Results}

The presentation of scores were presented in 3 scores, namely: the score of the knowledge aspect (basic competences 3.1, 3.2 etc.), the skill aspect (basic competences 4.1, 4.2 etc.) and the description. The description had a function as a result of the teachers' observations of the strengths or weaknesses of their students. Assessment in Gamelan Soepra was carried out not only to get score in learning, but this assessment was an indicator of the success of teachers in educating their students. Educating students to have musical skills as one of the assets in the future and educating students' attitudes that reflect human competence, compassion, conscience, and commitment. If in the test had a very significant difference in scores between one student and another, the teacher could find out which students should pay more attention to learning. This must also be supported by teacher observations of students in the daily learning process.

\section{CONCLUSION}

Music education at SMA Loyola uses Gamelan Soepra as an educational tool and Reflective Pedagogy as an educational method. Learning materials were provided to students through exploration of experiences of gamelan music given by the teacher, books (literacy), and experiences that they had experienced. This experience would be reflected in order to better understand the meaning and purpose of the material they learnt. This understanding would become a students' next action or after they had new knowledge. Then these actions would be evaluated in order to see the suitability of students' understanding of the material given.
Reflective pedagogy in Gamelan Soepra learning did not only aim at producing competent students in playing music, but also aims to develop a conscience, compassion and commitment. Compassion and Conscience were trained in the process of students practicing music in groups. Playing music in groups really required group interaction which required students to communicate and pay attention to one another and even to help each other. Then, commitment was obtained from how students underwent and completed the decisions they had made in Gamelan Soepra, namely in choosing a tool.

\section{REFERENCES}

Artanto, M. (2016). Mencermati Transit dan Transition dalam Aransemen Musik Nyanyian Negeriku Karya Singgih Sanjaya. Kajian Seni, 2(2), 132-150.

Aryanto, A. S. (2018). Gamelan Soepra: Konsep dan Perilaku Musikal untuk Mencapai Tujuan Pendidikan. Journal of Music Science, Technology, and Industry, 1(1), 111-118.

Desyandri. (2015). Pendidikan Seni Musik Humanis (Suatu Tinjauan Konseptual). Jurnal Prosiding Seminar Nasional Jurusan PGSD Universitas Negeri Padang, 1(1).

Fitriani, Y., \& Hadianda, D. S. (2016). Internalisasi Karakter Individu Melalui Pendidikan Musik Menuju Kerangka Konseptual Sebuah Kualitas Pembelajaran. Jurnal Pendidikan Dan Kajian Seni, 1(2), 140-153.

Maryani, A. (2002). Komunikasi Persuasif, Kohesi Kelompok dan Apresiasi Seni Gamelan Sunda: Kasus di Kalangan Mahasiswa. Jurnal Mediator, 3(2), 349172.

Moleong, L. J. (2002). Metodologi Penelitian Kualitatif. Remaja Rosda Karya.

Nugroho. (2008). Gamelan SUPRA (SUgijaPRAnata): Musik Pendidikan Humanisme Ignasian. Universitas Sanata Dharma. 
Ratna, N. K. (2010). Metodologi Penelitian Kajian Budaya Sosial Humaniora pada Umumnya (P. Pelajar (ed.)).

Riadi, A. (2017). Problematika Sistem Evaluasi Pembelajaran. Ittihad: Jurnal Kopertais Wilayah XI Kalimantan, 15(27), 1-12.

Rondhi, M. (2017). Apresiasi Seni dalam Konteks Pendidikan Seni. Jurnal Imajinasi, 11(1), 9-18.

Santoso, P. B. B. (2016). Penanaman Karakter Kejujuran pada Anak Melalui Komik Fiksi. Catharsis: Journal of Arts Education, 5(2).

Subagya, J. S. . (2010). Paradigma Pedagogi Reflektif, terjemahan dari ICAJE Ignatian Pedgogy: A Practical Approach. Kanisius.

Sugiyono. (2015). Metode Penelitian Pendidikan Pendekatan Kuantitatif, Kualitatif, dan R\&D. Alfabeta.

Sukari. (2012). Upaya Pelestarian Kesenian Daerah: Musik dan Lagu. Jantra, 7(2).

Sugiarto, E. (2019). Kreativitas, Seni \& Pembelajarannya. Yogyakarta: LKiS

Sugiarto, E. (2013). Pembelajaran Apresiasi Seni Berbasis Multikultural". Sabda: Jurnal Kajian Kebudayaan. Vol. 8 (1), $52-62$.

Sumaryanto, T. F. (2000). Kemampuan Musikal (Musical Ability) dan Pengaruh
Terhadap Prestasi Belajar Musik. Jurnal Harmonia, 1(1).

Sumaryanto, T. F. (2005). Efektifitas Penggunaan Metode Solfegio Untuk Pembelajaran Keterampilan Bermain Musik Di Sekolah Dasar (the Efektivity of Use of Solfigio Method To Teaching of Music Skill in Elementary). Harmonia: Journal of Arts Research and Education, 6(2).

Sumaryanto, T. F. (2007). Pendekatan Kuantitatif dan Kualitatif Dalam Penelitian Pendidikan Seni. UNNES Press.

Wahana, H. D. (2015). Pengaruh Nilai-Nilai Budaya Generasi Millennial dan Budaya Sekolah Terhadap Ketahanan Individu. Jurnal Ketahanan Nasional, 21(1), 14.

Wibowo, A. S. (2017). Paideia: Filsafat Pendidikan-Politik Palton. Kanisius.

Widodo, W. (2010). Lelagon Dolanan Anak dan Pendidikan Karakter. Harmonia, 10(2), 1-16.

Widodo, W. (2015). Laras in Gamelan Music's Plurality. Harmonia, 15(2), 34-45.

Widodo, W. (2018). Reaktualisasi Lelagon Dolanan Anak. Semarang. UNNES Press. 